\title{
Whales, Walruses, and Elephants: Artisans in Ivory, Baleen, and Other Skeletal Materials in Seventeenth- and Eighteenth-Century Amsterdam
}

\author{
Marloes Rijkelijkhuizen
}

Published online: 11 August 2009

(C) The Author(s) 2009. This article is published with open access at Springerlink.com

\begin{abstract}
Hard animal tissues obtained from whales, walruses, and elephants are baleen, whale bone, walrus ivory, walrus baculum, and elephant ivory. Objects of these materials were manufactured by artisans in Amsterdam in the seventeenth and eighteenth centuries. New archaeological and historical evidence show the import and importance if these materials. The importance of baleen is evident from historical sources. Whale bone and walrus penis bone were only used occasionally. The use of walrus ivory appeared to be of minor importance in comparison to elephant ivory. The Dutch elephant ivory trade in the seventeenth and eighteenth centuries is evident in historical and archaeological sources.
\end{abstract}

Keywords Whales · Walruses · Elephants · Artisans · Amsterdam · The Netherlands

Since the end of the sixteenth century, the Dutch Republic built up trade networks with different parts of the world. Amsterdam became an important staple market and a center of craft. Important trade companies were set up in the seventeenth century: The East India Company (Verenigde Oostindische Compagnie, VOC, 1602-1799) (Gaastra 2002), the first West India Company (Eerste Westindische Compagnie, WIC I, 1621-74), the second West India Company (Tweede Westindische Compagnie, WIC II, 1674-1791) (den Heijer 2002) and for trade in the north, the Noordsche Compagnie (1612-42). As a result of the foundation of these companies, many exotic materials found their way to the Dutch Republic.

Archaeological sources from Amsterdam, combined with historical sources, can give us more insight of the use of skeletal materials from whales, walruses, and elephants. They provide information on economic aspects such as trade and craft in these materials in seventeenth- and eighteenth-century Amsterdam. The Archaeological Service of Amsterdam has excavated over 2,000 objects made of hard animal

\footnotetext{
M. Rijkelijkhuizen $(\bowtie)$

Department of Environmental Archaeology, Amsterdam Archaeological Center, University of Amsterdam, Turfdraagsterpad 9, 1012 XT Amsterdam, The Netherlands e-mail: marloesrijkelijkhuizen@hotmail.com
} 
tissues such as bone, antler, ivory, horn, tortoise shell, hoof, and baleen that are dated between the twelfth and twentieth centuries. Of all these objects, $60 \%$ was made of bone, $33 \%$ of ivory, $4 \%$ of keratinous materials (horn, tortoise shell, hoof, and baleen) and 3\% of antler (Rijkelijkhuizen 2004).

\section{Whales}

Much has been written about the history of Dutch whaling. Literature on the subject dates from the eighteenth century onwards (see e.g., Dekker 1971; Frank 2005; de Jong 1784-86, 1972-79; Leinenga 1995; Lootsma 1937; Martens 1710; Muller 1874; Münzing 1987; Zorgdrager and Moubach 1727/28; for a full overview of the literature, see Hacquebord 1994). What follows is a short summary of Dutch whaling.

The First Dutch Whale Hunters and the Foundation of the Noordsche Compagnie

European whale hunting florished in the seventeenth and eighteenth centuries. The most important species of whale for seventeenth- and eighteenth-century whalers was the bowhead whale (Balaena mysticetus) (Hacquebord and Leinenga 1994, p. 420; Leinenga 1995, p. 39). This whale is a baleen whale and belongs to the family of Balaenidae. The advantages of the bowhead whale are that the blubber of this species is very thick and therefore contains much oil, it also has the largest baleen plates. Another whale of this family is the north Atlantic right whale (Eubalaena glacialis). This whale was also hunted, but gave less train-oil and shorter baleen plates than the bowhead whale (de Jong 1972-79, I, p. 14; Leinenga 1995, p. 55). Occasionally another species could be caught, such as sperm whale (Physeter macrocephalus/cetodon) or narwhal (Monodon monoceros), but this did not happen not very often (de Jong 1972-79, I, p. 14). The blubber of these big sea mammals was cooked to obtain train-oil, which was used for lamps, soap, and leather working (de Jong 1972-79, I, p. 39; Lootsma 1937, pp. 159-164). Baleen became an important product after the discovery of its qualities.

The Dutch whaling history started at the end of the sixteenth century, following the English example. Both nations, however, could not have developed whale hunting without the help of the Basques. The Basques had hunted whales for centuries, beginning in the twelfth century. Their experience was used to establish Dutch and English whaling, and Basques were the teachers of the northwest European whale hunters (Frank 2005, p. 204; Hacquebord and Vroom 1988; Hart 1976; de Jong 1972-79, III; Münzing 1987, p. 10).

At the end of the sixteenth century, the Dutch made several journeys to the north in search of a northeast passage to Asia. In this search they also noticed the whales and probably caught their first (small) whale near Russia (de Jong 1972-79, III, p. 32). They also visited Spitsbergen and discovered Bereneiland (Bear Island). The discovery of Bereneiland, however, was soon forgotten until rediscovered by the English; they called it Cherie Island (de Jong 1972-79, I, p. 29). In 1604 or 1605 the English Muscovy Company started to hunt seals and walruses at Cherie Island. Soon also Spitsbergen was visited for the walrushunt (Dekker 1971, p. 16; Hart 1976, p. 214; de Jong 1972-79, I, p. 30). In 1611, with help of the Basques, the 
English commenced whale hunting (Hart 1976, p. 214). The Dutch sent ships to the north for whale hunting beginning in 1612. The growing population of the Dutch Republic caused an increased demand for oils and soap (de Jong 1972-79, I, pp. 3739). These demands could be lifted by the train-oil obtained from the whales. Whaling also provided employment for many people.

The English did not tolerate any competition of other nations at Spitsbergen, and Dutch ships were attacked many times. To protect themselves from English hostilities Dutch whale hunters joined forces and founded the Noordsche Compagnie in 1614 (Muller 1874). Armed ships were now guarding the whale-ships and their cargo. The Noordsche Compagnie held a Dutch monopoly until 1642. This meant that no Dutch citizens other than those connected to the Noordsche Compagnie could hunt whales at the bays of Spitsbergen. The Muscovy Company and the Noordsche Compagnie divided Spitsbergen as if it was their own. Other nations that held a much smaller part of the whale hunt - for example, Denmark, France, and Spain-were also present at Spitsbergen. Newcomers had to catch whales at open sea. Basques processed the whales on their ships according to their tradition (de Jong 1972-79, I, p. 41).

The Noordsche Compagnie hunted whales in the bays of Spitsbergen and the whale products were prepared at land stations at "Smeerenburg" at Amsterdam Island, the Dutch territory at Spitsbergen. The number of whales in the bays however decreased rapidly as a result of intensive hunting and climate changes. Because of the diminishing population of whales in the bays, the whales were followed into the open sea and even into the ice (Hacquebord and Leinenga 1994). The products were now directly shipped to and processed in the homeland (Dekker 1971; Frank 2005, pp. 204-207). The stations at Spitsbergen were all abandoned at the end of the seventeenth century (de Jong 1972-79, I, p. 41).

\section{Free Trade and New Hunting Areas}

Because the monopoly of the Noordsche Compagnie only applied to the bay area of Spitsbergen, other Dutch ships were already catching whales at open sea before the monopoly of the company actually ended. In 1642, the monopoly of the company was not prolonged and whale hunting was permitted for any shipping company or ship owner. Many shipping companies and ship owners now participated in the whale hunt (Bruijn and Davids 1975; Dekker 1971). Because of irregular profits, whale hunting was often compared to a lottery (de Jong 1972-79; Leinenga 1995).

After a century of whale hunting at Spitsbergen, new hunting areas had to be found (Frank 2005, pp. 207-208). In the eighteenth century, Street Davis became the second most important whaling area (Leinenga 1995). Spitsbergen maintained its position as the most important place for whalers. At Street Davis Europeans traded with indigenous people before the whale hunt in this area actually started. According to Dekker (1976), this trade already existed at the end of the seventeenth century. Dutch whale hunting in this area, however, did not start until 1719 (Leinenga 1995).

\section{The End of Dutch Whaling}

At the end of the eighteenth century, Dutch whaling came to an end. This development was caused by many reasons, such as naval wars and increasing 
competition from various European nations that had developed their own whale hunt. But also a decreasing population of whales at Spitsbergen and rising costs were taking their toll on the Dutch whale hunt (Hacquebord 2005, pp. 104-105; Hacquebord and Leinenga 1994). Whale products were replaced by other products, and a few attempts to revive the Dutch whale hunting were never successful.

\section{Baleen Trade}

Baleen whales have a different feeding system from toothed whales. Baleen whales have baleen plates instead of teeth, with which they filter food from the water. Prices of baleen fluctuated strongly. Between the end of the seventeenth century and the end of the eighteenth century it varied between 25-250 guilders per $100 \mathrm{lbs}$ (Honig 1867; de Jong 1972-79, III, pp. 185-195; Leinenga 1995, p. 75). The amounts of baleen that were brought back to the Dutch Republic were not registered (Leinenga 1995, 59, 74). De Jong has estimated these amounts by looking at numbers of caught whales and oil imports. In the seventeenth century, 1-2 million pounds per year were not exceptional. In the eighteenth century, counting both Spitsbergen and Street Davis, it hardly reached one million pounds per year. In the second half of the eighteenth century, 500,000 lbs was normal, but reaching only 8,000 lbs in 1798 (de Jong 1972-79).

Whalers of different nations shared information on whale populations and traded whale products between them. Whaling nations traded whale products between themselves when sufficient whale products could not be obtained by hunting (Leinenga 1995, p. 59). Exports to non-whaling nations also occurred. Baleen was exported from Amsterdam to Germany, England, Scandinavia, France, Spain, Portugal, Russia, the southern Netherlands, and the Mediterranean. But baleen was also imported to Amsterdam from Germany, England, Scandinavia, France, Spain and Portugal (Leinenga 1995, pp. 85-91, 203-206; van Nierop 1915).

Between 1726 and 1731 an attempt was made by the West India Company (WIC) to set up whaling at the African coast, but this attempt however failed miserably (Dekker 1994). Shortly after this period, when prices of baleen were at their highest (Honig 1867; de Jong 1972-79, I, pp. 185-195; Leinenga 1995, p. 75), the Dutch East India Company (VOC) started trading baleen. In 1732, probably the first sample of baleen from Japan was brought to the Dutch Republic (Coolhaas and van Goor 1988, 2004). The VOC experimented with the import of baleen from Japan to the Dutch Republic. A list of products that were sold in the different chambers of the VOC records a total of 23,691 lbs of baleen imported between 1733 and 1738, with a value of little more than 23,246 guilders. The average price per pound was 136 cents. The baleen sheets were sold in Amsterdam, Zeeland, Delft, Rotterdam, Hoorn and Enkhuizen. (Nationaal Archief, VOC 6989). But more baleen was probably imported from Japan in this period. The VOC, however, succumbed to the protests of the Dutch whale hunters in the north, the so-called "Greenland traders," after a few years and ended the trade in baleen from Japan (Nationaal Archief, Radermacher 129). Trade in baleen with the Japanese was supposed to end in 1737, but it could not be terminated until 1738 (Coolhaas and van Goor 1988, 2004). 
In Search of a Use for Baleen

A primary reason for the start of the European whale hunt was train oil. When the qualities of baleen were discovered, prices rose and many products were made from baleen sheets, especially corset strips. Before the use of baleen was known, people sought a purpose for this strange material. Excavations at Spitsbergen produced many baleen waste fragments in the context of the early period of Smeerenburg. This find indicates that baleen was not in high demand. Whalers tried to find a purpose for this material, and baleen even has been used as a building material at Smeerenburg (Hacquebord and Vroom 1988, pp. 52-53). The Noordsche Compagnie was in search of possibilities for this material and they asked John Osborn to find a purpose for the big sheets of baleen.

Baleen, like horn and tortoise shell, consists of keratin. Baleen sheets, in contrast with the other keratin based materials, have three different layers. The middle layer consists of keratin tubules, on both sides a layer of keratin covers this tube layer. Several of these sheets are connected to each other at the base. The fringes at the end of the sheets filter food from the water (MacGregor 1985; O'Connor 1987). The advantages of baleen as a material are that it is elastic and lightweight. An important quality of keratin-based materials is that these materials are thermoplastic. This means that it can be formed in any shape using heat; after cooling it retains its new shape (O'Connor 1987). These qualities were used by John Osborn (1581/4-1634) to find new techniques to process baleen at the request of the Noordsche Compagnie. John Osborn was born in England and moved to Amsterdam around 1600. In spite of competition, he received his first patent in 1618. After his first patent two more followed, the last one ending in 1630 . He invented not only new methods to work baleen, but also a method to press it using metal molds. By pressing the baleen, any shape could easily be obtained, and medallions and reliefs were made. Some of these pressed objects were apparently painted black, and resembled ebony. Baleen was also used as a veneer for frames and cabinets (Lootsma 1937, pp. 165-167; Muller 1915; van Thiel 1969; van Thiel and de Bruyn Kops 1984). Pressed baleen objects and frames with baleen veneer are in possession of various Dutch museums (Hacquebord and Vroom 1988; van Thiel 1969; van Thiel and de Bruyn Kops 1984). A relief panel "The Bacchanalian Frolic," made by John Osborn and Jan Lutma, is in possession of the New Bedford Whaling Museum (collection of the former Kendall Whaling Museum) (Lauffenburger 1993).

\section{Baleen Workers in Amsterdam}

The imported baleen was mostly sold and processed in Amsterdam. Baleen sheets were cleaned and bundled before shipment and sale (Dekker 1971, p. 23; Honig 1867, p. 72; de Jong 1972-79, I, p. 143; Leinenga 1995, p. 22). The names of many baleen workers in Amsterdam are known from historical sources (Wagemakers 1992). Shops and artisans specialized in the sale or the processing of baleen sheets. Some of them only abraded or cut the baleen, others were specialized in making corsets. Baleen could also be used for other objects such as umbrellas, fans, and knife handles (Lootsma 1937, p. 164), but the main use was for corset strips. Baleen 
was used for corset strips because it is lightweight and because of its elasticity. Its thermoplastic nature also makes it easy to process.

Information on the income of craftsmen can be found in the Kohier personeele quotisatie from Amsterdam in 1742. The profession, possessions, rent, and income of everyone in Amsterdam who made more than 600 guilders a year were recorded to determine taxes. This document indicates that 12 baleen buyers or shops were present in the city. They earned a salary between 800-6,000 guilders a year, which was quite an amount in that period. In the same year 12 corset makers and six corset shops existed in Amsterdam. They had salaries between 600-2,000 guilders a year (Oldewelt 1945).

The Absence of Baleen in Archaeology

Although baleen was an important product for the Republic and was used by several artisans, it is a rare archaeological find. Even though it was much used in Amsterdam, only two waste fragments of baleen have been found in excavations in Amsterdam (Rijkelijkhuizen 2004) (Fig. 1). Both pieces date to the eighteenth century. No other finds of archaeological baleen are known in the Netherlands. In other countries, such as England, baleen is also absent in archaeological collections (O'Connor 1987). This paucity probably results because baleen is difficult to identify and because preservation in the soil is problematic. The conditions of the soil in Amsterdam are favorable for materials such as horn and baleen, but the number of baleen finds are still low (Rijkelijkhuizen 2004). Another important factor is that little baleen was wasted. Even the waste from the baleen plates was used for filling couches (O'Connor 1987). Expensive baleen objects such as decorated boxes, frames, and reliefs are present in museums and are not likely to be found in excavations. It is also possible that baleen strips for corsets were reused.

\section{Whale Skeletal Bone}

In contrast to baleen, whale bone was not an important material for artisans (Rijkelijkhuizen 2004). It was sometimes used as a building material or to obtain oil. The usage was simple and limited to the use as tombstones, church benches, sign boards, and other objects (Dekker 1971, p. 23; Lootsma 1937). At Spitsbergen whale bones were found which were used as the foundation of a fire place or as a foundation for house poles (Hacquebord and Vroom 1988, pp. 58, 71). This usage of
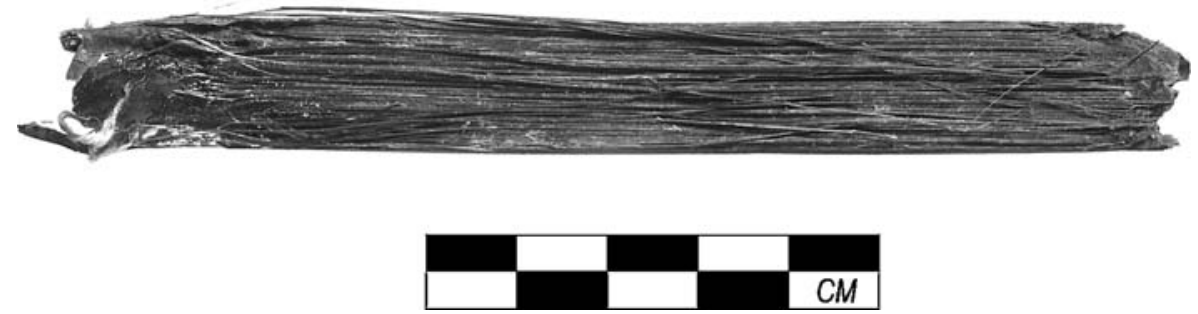

Fig. 1 Baleen waste piece, eighteenth century. (Collection, Afdeling Archeologie BMA/Amsterdams Historisch Museum. Photograph, Anneke Dekker, AAC) 
whale bones was probably born out of shortage of building materials. At the Wadden Islands of the Dutch Republic whale bones were used as fence poles, church benches, and tombstones (Lootsma 1937). The use of whale bone in the Republic was not restricted to practical uses as a result of a shortage of building material. In other parts of the Republic, whale bones were used as signboards. Although a practical reason for the use of bone instead of wood could be that bone did not rot as fast as wood, it probably also had a symbolic function (Brongers 1995; Dekker 1971, p. 45). Whale bones were furthermore brought home as proof of the amount of whales caught or to show the great size of whales to non-believers (Lauwerier 1983).

Whale bones do not contain marrow but a kind of oil (de Jong 1972-79, I, p. 10; Lootsma 1937, p. 164). Sometimes holes were drilled in the big whale bones which would then be put upright on deck on the homeward journey (Dekker 1971, p. 23). In this way the oil could be obtained out of the greasy bones. It did not provide much oil and was not of great economic use, but provided only a little extra money for the crew (Lauwerier 1983).

The use of whale bones as a raw material for the manufacture of small objects by artisans was not very common in the Republic. In Amsterdam only one object made of whale bone has been found, a knife handle with the initials H V (Rijkelijkhuizen 2004) (Fig. 2). These initials were probably made by its owner, who may have been a whaler. He even could have made the knife handle himself. Whalers sometimes made small objects on board ship. The small number of archaeological finds of whale bone objects indicates that whale bone was not used by craftsmen (Rijkelijkhuizen 2004), a conclusion supported by the non-mention of whale bone in the inventories of knife makers in Amsterdam. Whale bone was probably not used by craftsmen because more suitable and useful materials were available, such as regular, odor-free bones and elastic ivory. Whale bone objects remained a rarity in public life.

\section{Walruses}

Walrus hunting existed in northern Scandinavia and Russia during the medieval period. In these areas, walruses (Odobenus rosmarus) are natural inhabitants and hunting them was a common practice. For northwestern European countries like the Dutch Republic and England walrus hunting did not start until the beginning of the seventeenth century. English walrus hunting started in 1604 or 1605 at Cherie Island (Dekker 1971, p. 16; Hart 1976, pp. 213-214; Houttuijn 1761; de Jong 1972-79, I,

Fig. 2 Knife handle from whale bone. (Collection, Afdeling Archeologie BMA/Amsterdams Historisch Museum. Photograph, Anneke Dekker, AAC)
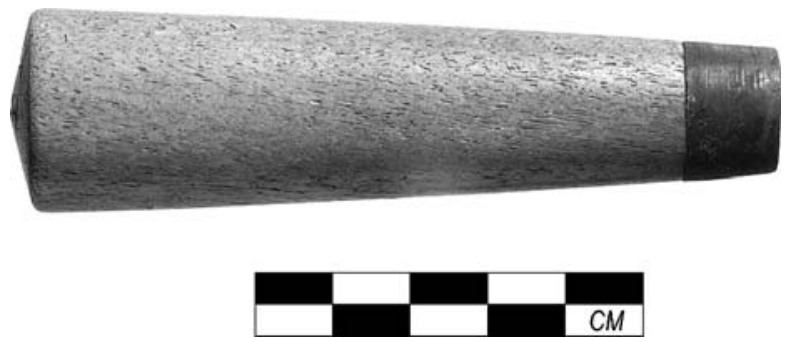
p. 150). Inhabitants of the Dutch Republic followed the English example and soon were catching walruses as well (Dekker 1971, p. 17). Eighteenth-century sources mention large walrus slaughters by the Dutch in the seventeenth century. More than 900 walruses were supposed to be killed at one time in the year 1608 (Houttuijn 1761, pp. 11-12). Other large slaughters were made by Ryke Yzesz. in 1640 or 1645 (de Jong 1784-86, pp. 44-45). Sometimes even a living walrus was brought back to the Republic for display (van Bree 1996).

The large walrus slaughters did not last long. Houttuijn (1761) mentions reasons for the rapid decline of the Dutch walrus hunt. The walruses became cautious and no longer appeared in large groups. Many walruses were caught by the English and the Dutch, and the walrus population was already declining because of intensive hunting (Dekker 1971, pp. 16-17). When the whale hunt started, walrus hunting became less important. Walruses had been hunted for their oil and teeth and sometimes for their skin. For economic reasons whales were much more appreciated because they provided much more blubber (Houttuijn 1761; de Jong 1972-79, p. 150.). Therefore, in a later period, when walruses were caught, only the teeth or the heads with the teeth were collected and the rest of the animals discarded (Hart 1976, p. 259). When the whale hunt moved from land to the open sea, the hunters were also further removed from the walruses and it is more difficult to catch walruses in the water than on land. No big herds of walruses appear in the water, and walruses are much faster there. The emphasis of the hunt shifted from walruses to whales (Dekker 1971, pp. 16-17).

The numbers of walruses that were caught are difficult to estimate. Some large walrus slaughters by the Dutch from the seventeenth century are known, but these could be exaggerated. In a later period Cherie Island, where most walruses could be found, was only visited sporadically. In 1702, with recovery of a ship near Cherie Island, 1,799 walrus teeth were acquired. These teeth and a walrus head were worth 7,913 guilders (Hart 1976, pp. 257-264). At Spitsbergen between 1712 and 1766 no walruses are recorded to have been caught. In 1767, 4,075 walruses were killed; in 1822, only 20 walrus kills are recorded (de Jong 1972-79, I, pp. 279-283).

\section{Trade in Walrus Ivory}

From the tenth to the twelfth century, trade with Scandinavian countries brought walrus ivory to England and many objects were made of this material (MacGregor 1985 , p. 40). For the Netherlands no such trade is proven and future research must reveal the use of ivory, walrus, and elephant in this period. Besides the small amount of walrus teeth from the walruses at Cherie Island and Spitsbergen, it is possible that the Dutch obtained some walrus teeth through barter with the local Inuit at Street Davis. Only small trade was allowed (Leinenga 1995, p. 154), and probably only a few walrus teeth were brought back from this area.

Walrus teeth were also imported from Russia (Houttuijn 1761, pp. 12-13). From the sixteenth century onward, the trade between the Netherlands and the Baltic Sea area and Russia became an important one. From the Baltic Sea mainly grain was imported and trade with this area has been called the "mother trade" and was said to be the basis of the golden age of the Dutch Republic. From Russia products such as different kind of furs, hides, and wood were imported. Dutch and English traders 
established posts in these areas (for trade with Russia, see e.g., Veluwenkamp 2000; Wijnroks 2003). Walrus teeth were probably only imported in small amounts, but more research must be completed on this subject.

Although more profit could be obtained on a price-per-pound basis, trade in walrus ivory was of minor importance to the Dutch. The large amounts of elephant ivory that could be imported to the Dutch Republic made it more profitable. Elephant ivory was also easier to work because of its absence of secondary dentine. The trade in elephant ivory was important in the Dutch Republic in the seventeenth and eighteenth centuries (den Heijer 1997; Rijkelijkhuizen 2004).

\section{Walrus Ivory and Artisans in Amsterdam}

Walrus ivory is obtained from the upper canines of the walrus and can be up to $1 \mathrm{~m}$ long. Walrus ivory can be recognised by the two types of dentine that are present. The primary, outer dentine is very homogenous; the secondary, inner dentine has a very typical chaotic structure. A thick cementum layer can be present at the outer side of the tusk (Espinoza and Mann 1992; MacGregor 1985; O'Connor 1987; Penniman 1952; Thornton 1981). Prices were higher than that of elephant ivory (de Jong 1784-86, p. 44).

Research of the over 2,000 objects of hard animal tissues shows that in Amsterdam in the seventeenth and eighteenth century, ivory was an important raw material for the production of objects. This was mostly elephant ivory, as walrus ivory was rarely used. Among the more than 700 ivory finds, only four objects are identified as walrus ivory (Rijkelijkhuizen 2004). These are two knife handles, a small brush with an earscoop at the other end (Fig. 3), and an object with unknown function. This last piece could also be an unfinished object or a waste fragment. The unknown object and one of the knife handles are dated to the eighteenth century.

The small brush with earscoop resembles similar small brushes made of elephant ivory (see Fig. 3). Elephant ivory was only used by artisans. The similarity in shape and size indicates that the brushes were made by professional artisans in the Dutch Republic who worked both materials. Historical sources support this interpretation. Houttuijn (1761, pp. 12-13) mentioned that walrus ivory was used for the manufacture of knife handles. The inventories of two knife makers in Amsterdam, Pieter Meijerick in 1691 (Stadsarchief Amsterdam, notarial 4711) and Menso Sadelaer in 1708 (Stadsarchief Amsterdam, notarial 7479), show that the products they had in their shops were mainly knives with knife handles made of ivory, bone, and tortoise shell. The raw material - elephant and walrus ivory-was also present in the shops. However, the amount of elephant ivory far exceeds the amount of walrus ivory. The estimated price of walrus ivory in the inventory of Pieter Meijerick was 100 cents per pound, for elephant ivory it was 70 cents per pound. The price of the knife handles themselves vary and seem to be dependant on the raw material used and the kind of knife handle. The amount of work was calculated in the price of the knife handles as well as the raw material used. Artisans also knew that the secondary dentine could be made visible in objects, and the chaotic structure was used as decoration in knife handles (Houttuijn 1761, pp. 12-13).

It is possible that knives with knife handles of walrus ivory stayed in families for a long time. An example of this is the cutlery with walrus ivory handles of Dutch 
Fig. 3 Four small brushes with toothpick or ear scoop, made of, from left to right: elephant ivory, ivory, walrus ivory and bone. (Collection, Afdeling Archeologie BMA/Amsterdams Historisch Museum. Photograph, Anneke Dekker, AAC)
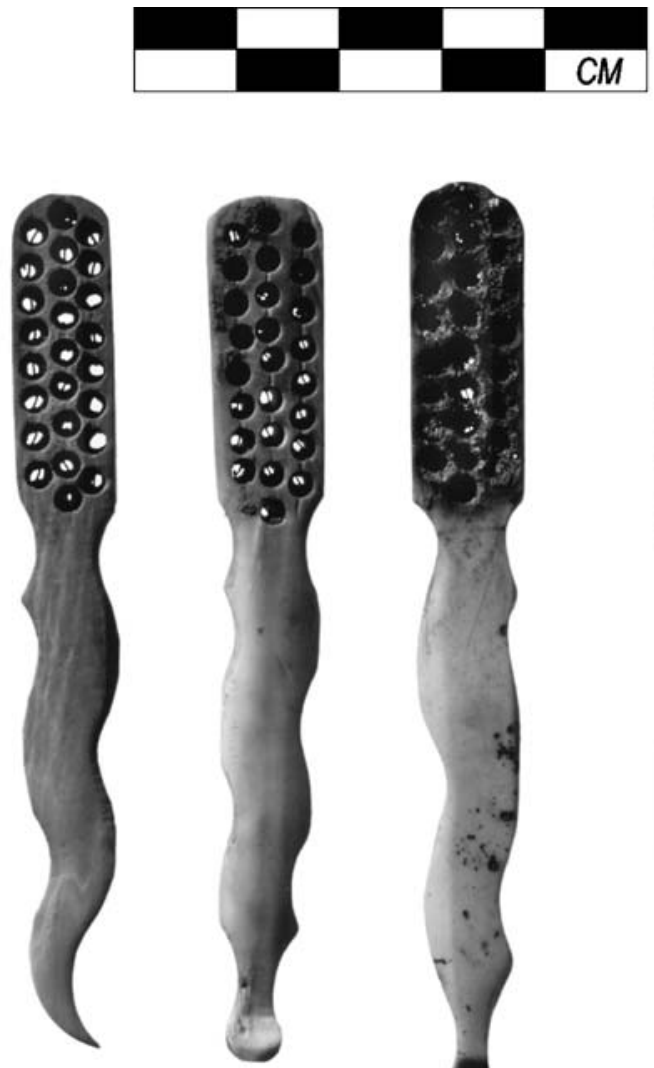

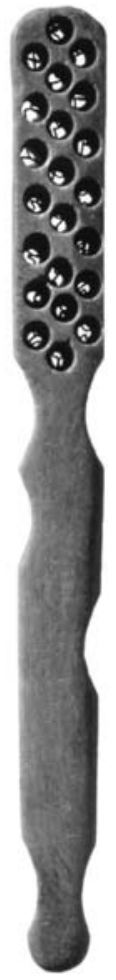

whaling captain Mooy. This cutlery was used by him and his descendants, and the objects remained in the family until his great-granddaughter gave them to the Maritime Museum in Amsterdam (Mooy 1946).

\section{Knife Handles of Walrus Baculum}

A walrus baculum (penis bone) is very large and solid. It does not have a marrow cavity as other bones have; it only has a small quantity of spongy bone in the middle. Four knife handles from excavations in Amsterdam are made of walrus baculum (Rijkelijkhuizen 2004). One of these handles is dated to the sixteenth or seventeenth centuries (Fig. 4), another is dated to the seventeenth century. The other two are of uncertain date. Two of the knife handles are beautifully decorated. Knife handles with the same decoration are made of elephant ivory (Rijkelijkhuizen 2004). The similarity in decoration suggests that professional artisans who made knife handles of elephant ivory sometimes also used walrus baculum. The inventory of knife maker Menso Sadelaer shows that this is indeed the case. In this inventory not only large amounts of elephant ivory are written down, but also a small amount of walruskranen used as a raw material for the manufacture of knife handles. 

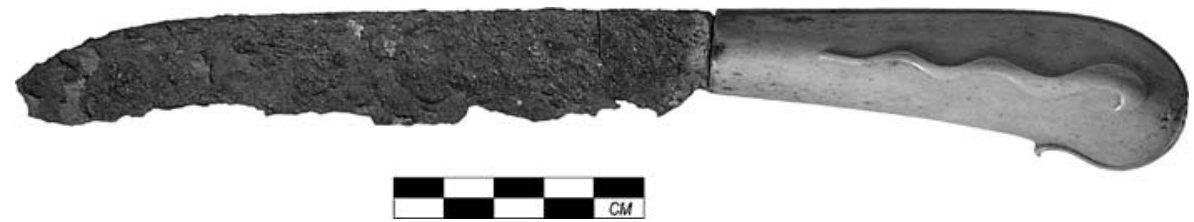

Fig. 4 Knife with handle of walrus penisbone, sixteenth or seventeenth century. (Collection: Afdeling Archeologie BMA/Amsterdams Historisch Museum. Photograph, Anneke Dekker, AAC)

Some of the knife handles of walrus baculum that have been found in Amsterdam are worn by intensive use; the decoration of one of the handles is almost completely worn off. This handle has been used for a long time and could be passed to descendants, just as the cutlery of walrus ivory from Captain Mooy. It is also possible that sailors and whalers possessed cutlery with walrus baculum handles.

\section{Elephants}

The importance of the elephant ivory trade of the Dutch Republic is evident from both historical (Feinberg and Johnson 1982; den Heijer 1997; Postma 1973) and archaeological sources (Rijkelijkhuizen 2004). Tusks from African elephants (Loxodonta africana and/or Loxodonta cyclotis) were imported by the Dutch West India Company (WIC) from West Africa to the Dutch Republic. For example, between 1675 and 1731 the WIC imported a total amount of 2,955,533 lbs of ivory with a market value of 2,512,280 guilders from the Gold Coast. This amounts to $10.3 \%$ of the total cargo (den Heijer 1997). Part of the African ivory was exported from the Republic, mainly to Asia. The ivory that remained in the Republic was crafted into many objects (Rijkelijkhuizen 2004).

The immense import of elephant ivory can also be seen in the archaeological data from Amsterdam (Rijkelijkhuizen 2004). Of all the objects found in Amsterdam made of hard animal tissues $33 \%$ was made of ivory. The importance of ivory as a raw material becomes even clearer when looking at the percentages of bone and ivory objects through time (Fig. 5). The ivory objects are compared with the bone

Fig. 5 Percentage of bone and ivory objects from Amsterdam through time

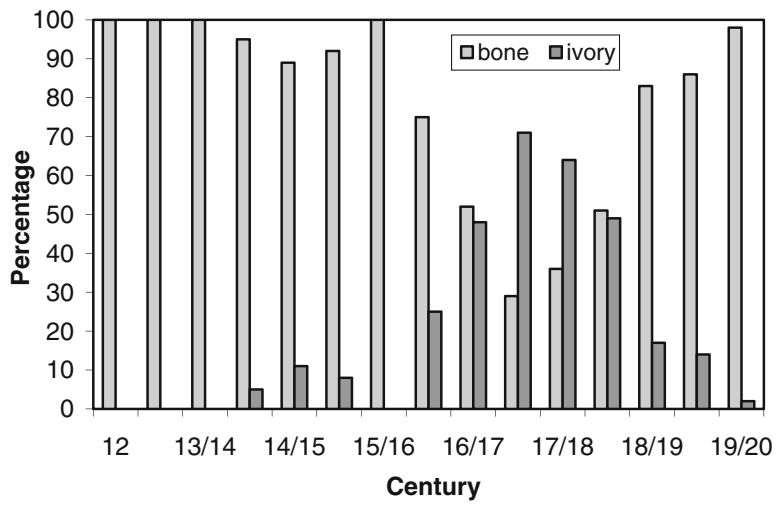


objects because bone was a frequently used material throughout time. Antler was little used in this period and keratinous objects are not suitable for comparison because of their rapid decay in the soil. The percentage of ivory objects surpasses the percentage of bone objects in the seventeenth and eighteenth centuries. In the eighteenth century, the number of objects made of ivory still increased, although slightly more bone objects were found. Ivory became a frequently used material in seventeenth- and eighteenth-century Amsterdam. After the eighteenth century, the finds of ivory objects decreased rapidly.

\section{Archaeological Ivory Objects from Amsterdam}

The large incisors of elephants were used for the manufacture of many objects. Elephant ivory is easy to identify by the so-called "Schreger lines." These crossing lines appear on the cross-section of elephant tusks and are seen on the ivory objects made from these tusks. The tusk is covered with a small layer of cementum on the outer side (Espinoza and Mann 1992). Elephant ivory is easy to work and can be well polished; also it is less breakable than bone (Rajaram 1986).

Most of the items made of elephant ivory excavated in Amsterdam are combs; 348 out of a total of 438 combs were made of elephant ivory (Rijkelijkhuizen 2004) (Fig. 6). Elephant ivory was used for these combs because fracturing this material is more difficult than bone. Combs with fine teeth could not be made of bone. These ivory combs show little variation; almost all the combs are rectangular and twosided, mostly with two fine sides (see Fig. 6 left). Some of the combs have a fine and a coarse side, sometimes with a simple decoration of lines (see Fig. 6 right). Only a few combs have a different shape or are one-sided. The purpose of these combs was to remove lice and nits from the hair; these combs are therefore called lice combs. Many combs show scratches running from the base of the teeth to the middle part of the comb. These scratches have been interpreted as the result of cleaning the comb (Schelvis 1992). The length of the combs varies from 29.3-124.9 mm, the width from $28.5-79.4 \mathrm{~mm}$, and the thickness from $0.8-7.7 \mathrm{~mm}$. The combs date from the end of the sixteenth century onwards, even though most combs date to the seventeenth and eighteenth centuries.
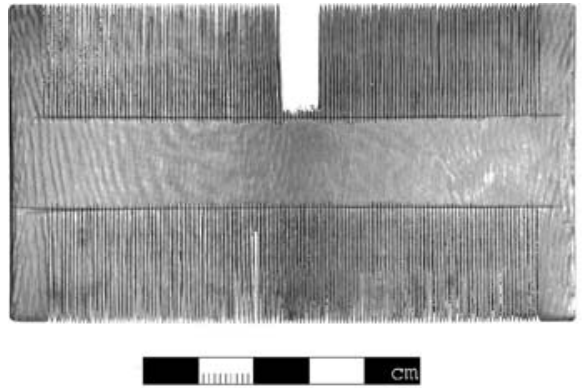

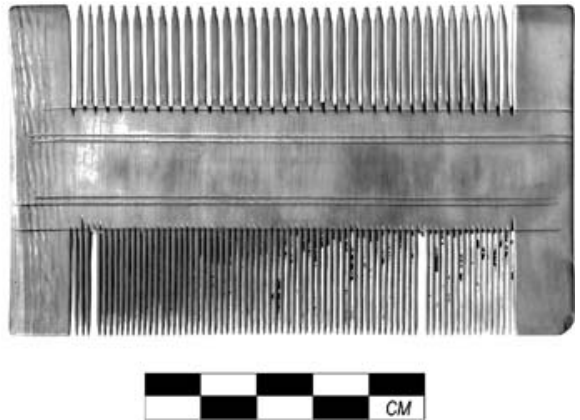

Fig. 6 Two elephant ivory lice combs. Photo: Anneke Dekker, AAC. Collection: Afdeling Archeologie BMA/Amsterdams Historisch Museum 
Another category of ivory object is knife handles, 160 knife handles are made of elephant ivory (Rijkelijkhuizen 2004) (Fig. 7). Bone was a good material for making knife handles, but only 121 knife handles are made of bone. Other knife handles excavated in Amsterdam are of antler and horn, although in small amounts (30 antler, 11 horn). The length of the ivory handles varies from $43.3-143.5 \mathrm{~mm}$ and thickness from 7.1-31.2 mm. These knife handles mainly date to the seventeenth and eighteenth centuries.

Various other objects were made of elephant ivory. These have different functions including toys and playing pieces, objects for personal care, objects for knitting and needlework, and parts of musical instruments. Other examples include dice, fans, brushes, needles, piano keys, buttons, syringes, and boxes (Rijkelijkhuizen 2004).

Ivory Workers in Amsterdam

Archaeological, historical, and iconographical sources show that the production of ivory combs was located in Amsterdam. The specialized character of comb making is indicated by the large numbers of combs that were all made in the same way (see below). Finds of unfinished combs are evidence that comb makers were established in Amsterdam (Fig. 8). One trial piece exhibits practice work in sawing the teeth, an indication that comb makers were also trained in Amsterdam (Fig. 9). Numerous waste fragments from the production of ivory objects were also found (Rijkelijkhuizen 2004).

The profession of ivory comb maker is mentioned in historical sources in Amsterdam, and a contract between three comb makers in Amsterdam at the beginning of the seventeenth century specifically mentions ivory as a raw material (van Dillen 1929, no. 1032). Historical sources also show that comb makers were educated in Amsterdam. A 15-year old boy was trained to make combs of ivory, tortoise shell, and horn (van Dillen 1929, no. 378). Another 15-year old boy was trained to make all sorts of combs (van Dillen 1929, no. 574). It seems that some comb makers only used ivory as a raw material while others used various materials. The income of a comb maker in 1742 could vary between 600-1,000 guilders per year. Three comb makers were recorded in this year. The owner of a comb shop at the Egelantiersgracht made 600 guilders per year (Oldewelt 1945).

An iconographic source is a book with engravings on different professions by Jan Luijken (1649-1712) and his son Kasper (1672-1708), which was first published in 1694 in Amsterdam (Luijken and Luijken 1694). One of the professions depicted was that of the comb maker (Fig. 10 left). The raw material is to be seen on the floor

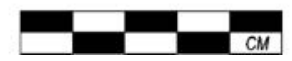

Fig. 7 Knife with elephant ivory knife handle. Photo: Anneke Dekker, AAC. Collection: Afdeling Archeologie BMA/Amsterdams Historisch Museum 

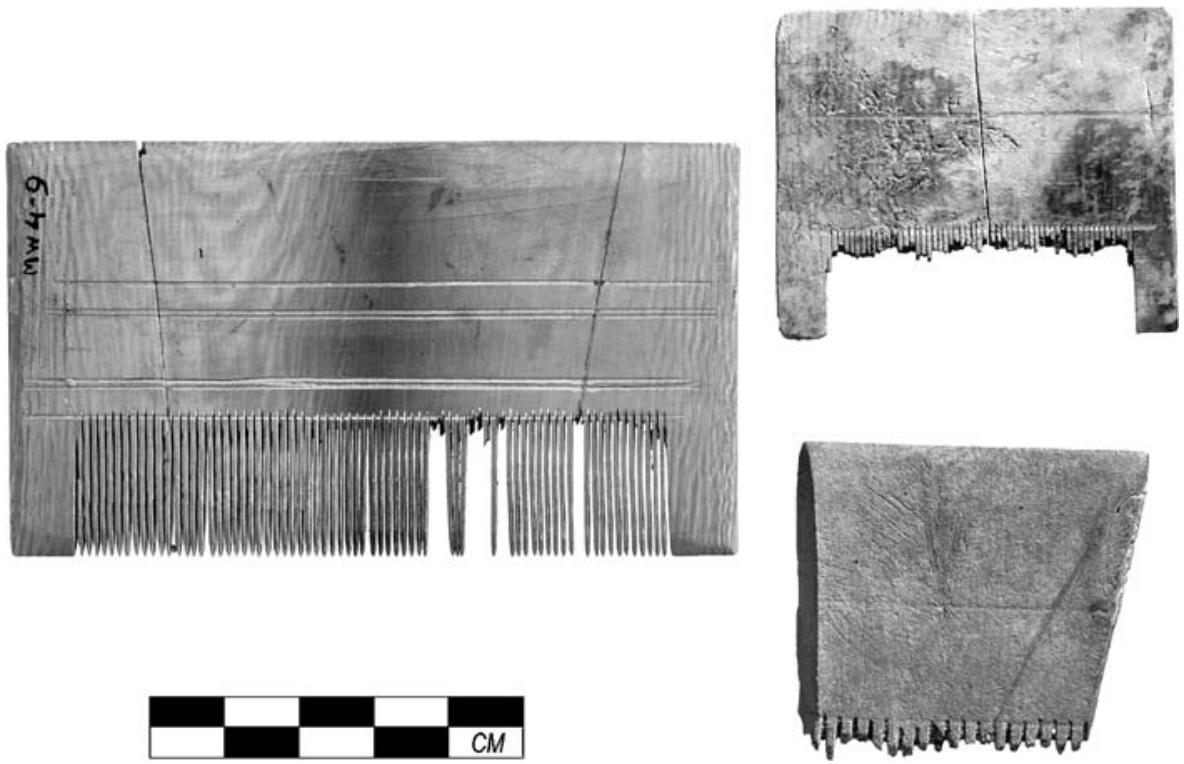

Fig. 8 Three unfinished combs. Photo: Anneke Dekker, AAC. Collection: Afdeling Archeologie BMA/ Amsterdams Historisch Museum

and a block of raw material is sawn by two craftsmen. The manner of manufacture shows that this material is ivory rather than horn. A horn is for the most part hollow, and splitting and flattening of the horn therefore proceeds the manufacture of horn combs. Such blocks could only be made of ivory, which is one-half to two-thirds

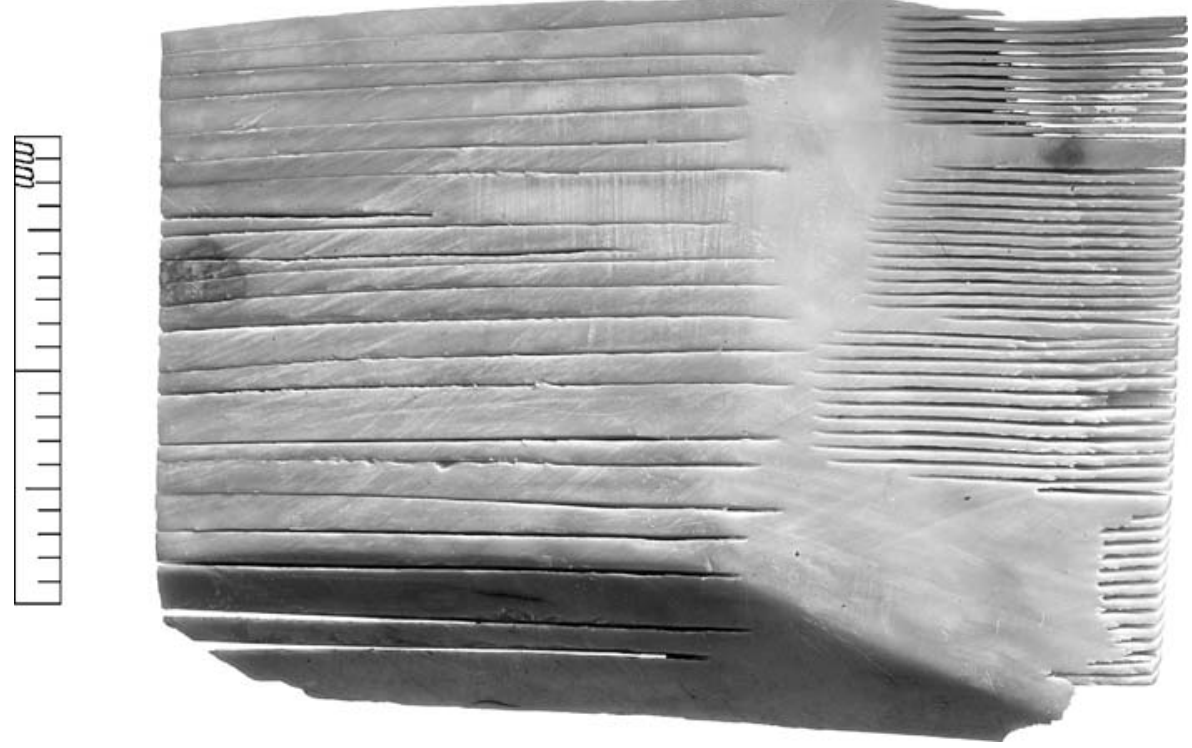

Fig. 9 Trial piece. Photo: Anneke Dekker, AAC. Collection: Afdeling Archeologie BMA/Amsterdams Historisch Museum 

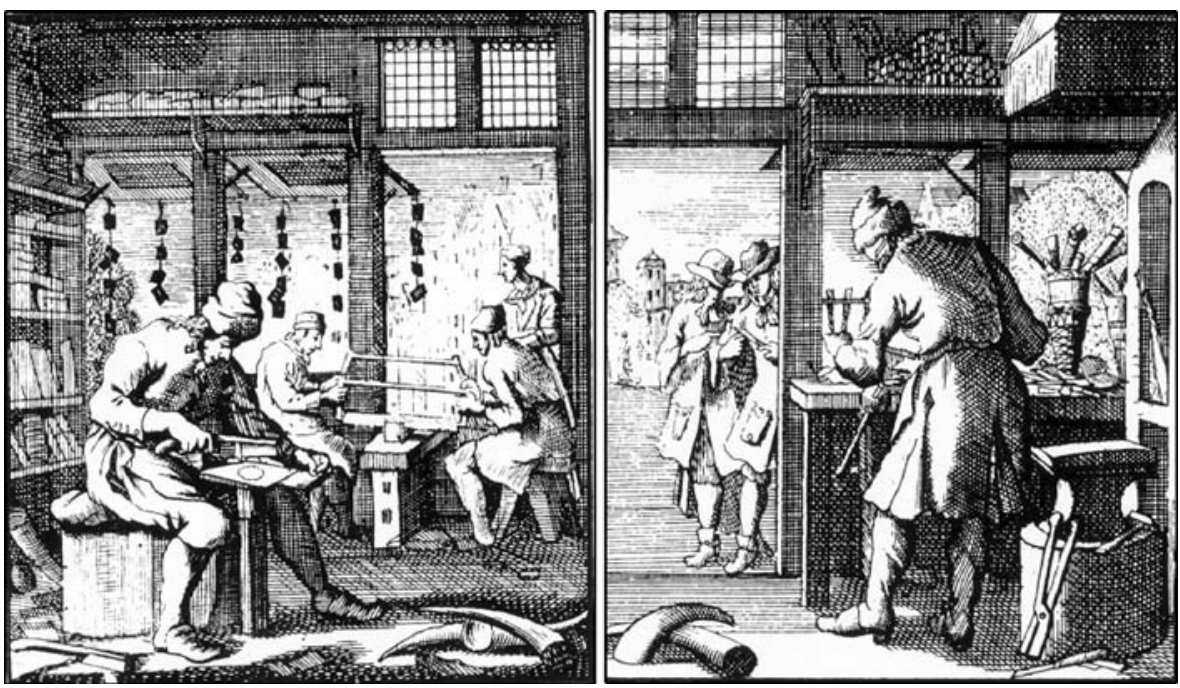

Fig. 10 Two professions. Engraved by Jan and Kasper Luijken: The comb maker and the knife maker

solid material. The raw material seen in the engraving is thus interpreted as elephant ivory. Ivory of animals other than elephants was not used for the manufacture of these combs (Rijkelijkhuizen 2004).

Many ivory knife handles have been found in excavations in Amsterdam. Knife makers or knife handle makers also appear in historical sources. The inventories of two knife makers in Amsterdam mentioned above show that they sold knives with ivory, tortoise shell and bone handles, and sometimes knives with walrus ivory or wooden handles. One of them had large amounts of elephant tusks in his shop. Both also sold combs of different material and some other small objects. A knife maker that was recorded in the year 1742 made 600 guilders a year. Nineteen knife shops are mentioned, with the makers' salaries ranging from 600-2,000 guiders a year (Oldewelt 1945). This profession was also engraved by Jan and Kasper Luijken (see Fig. 10 right). On this picture finished knifes including the handles are to be seen. On the floor, the raw material for those handles is present. These are probably elephant tusks.

Ivory was not only used by comb makers and knife handle makers, but could also be used by different other craftsmen, such as (ivory) turners, carvers and furniture makers, who used ivory as inlay material. Hilgert Laurenssom, an ivory turner that is registered in the "Kohier" of 1742, made 800 guilders a year (Oldewelt 1945). Some objects are made entirely, others partly of ivory. Archaeological finds show ivory objects with many functions used everyday by different classes of society. Ivory objects in museums are reliefs, cabinets, and sculptures; some ivory pieces exhibit small paintings.

\section{Manufacturing Process of Ivory Combs}

Waste fragments found in excavations in Amsterdam are not only important evidence for the manufacture of ivory objects in Amsterdam, but can also offer insight into the manufacturing of the objects. A total of 72 elephant ivory waste 
fragments was found and most of these fragments have the same shape. The fragments are long and on one end triangular in cross-section. One of the angles of this triangle is $90^{\circ}$; one of the sides is long and straight, one is short and straight, and one is slightly curved (Fig. 11). This curved outer side corresponds with the outside of the tusk and the cementum (outer layer of the tusk) is often present. These waste fragments are an indication of the way the tusks were divided before the manufacture of objects. By looking at both the waste fragments and the combs it is possible to reconstruct the dividing of the tusks (Rijkelijkhuizen 2004).

At first the hollow part at the base of the tusk and the tip of the tusk were removed. One of the tips has been found in excavations in Amsterdam. Then the solid part of the tusk was divided into several slices, depending on the length of the tusk (Fig. 12a-c). One slice was further divided into blocks (Fig. 12d-f). When this was done as proposed, the shape of the waste fragments corresponds with the excavated waste pieces. Other evidence for dividing a slice of tusk into such blocks comes from the combs. The structure of the elephant ivory shows that the combs are all cut from the tusk in the same way and that the smaller combs are made from the outer side of the tusk (see Fig. 12g-h). On both edges of the combs pieces of cementum are often present. These features are the result of dividing of the tusks into

Fig. 11 An elephant ivory waste fragment

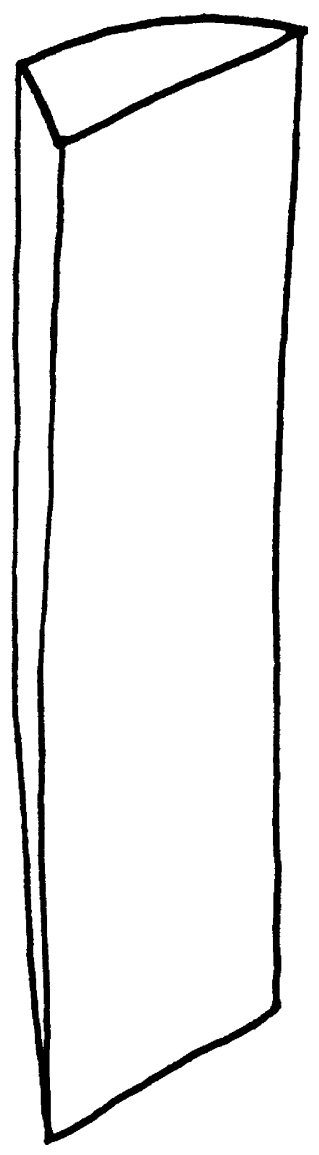


such blocks. After the division of the tusk into blocks, the blocks were sawn longitudinally in thin slices for the manufacture of combs, as can be seen in the picture by Jan and Kasper Luijken (see Fig. 10 left).

This process of manufacture is important to recognize because it proves that artisans were familiar with the properties of ivory. It is likely that ivory is stronger and less easy to break in longitudinal direction than in transverse direction. Combs of bone and antler are known to have been made in this direction (MacGregor and Currey 1983).

The unfinished combs found in Amsterdam show the manner in which the combs were manufactured from thin slices of ivory (see Fig. 8). The edges of the combs were rounded before the teeth were sawn, so that the individual teeth needed less additional rounding. Before the teeth were sawn, two lines were made on each side of the comb to give an indication of how far the teeth should be sawn. The saw was put oblique on the comb to make the angle between the comb and the saw smaller than $90^{\circ}$. In this way, it is easier to saw straight than if the saw was put in a right angle to the comb. When, however, the saw is put oblique to the comb, the teeth will be longer on the front side than on the backside of the comb. This feature is seen on some of the combs from Amsterdam. Possibly those combs were not finished yet. To finish the sawing of the teeth, the comb must be turned and the teeth sawn again

\section{Dividing of the tusk in slices (side view)}

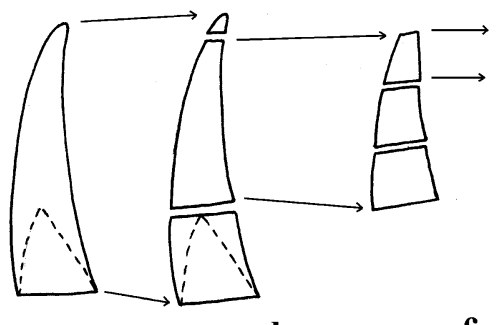

a.

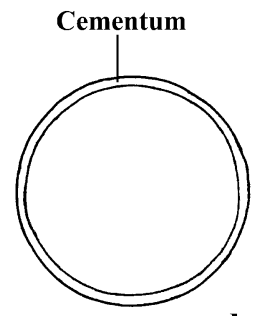

d. c.

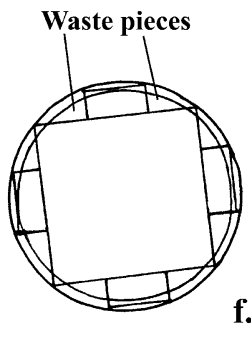

\section{Dividing of a slice in blocks (cross-section)}

Position of the
combs in the
tusk
(cross-section)
and in one of the
blocks
(side view)

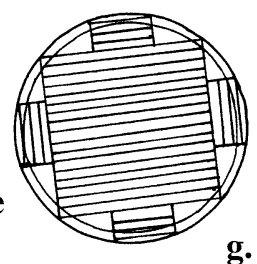

g.

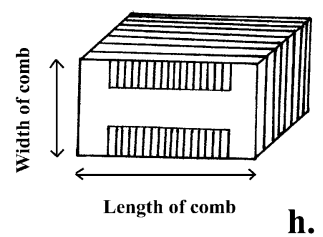

h.

Fig. 12 Schematic reproduction of the dividing of a tusk into slices $(\mathbf{a}-\mathbf{c})$, the dividing of a slice into blocks $(\mathbf{d}-\mathbf{f})$ and the position of the combs $(\mathbf{g}-\mathbf{h})$ 
from this side. As a result the teeth are also stronger, because they are connected with a bigger area to the comb (Fig. 13). To complete the comb, the teeth were sharpened and the comb was probably polished.

The manufacture of ivory knife handles can be deduced from the waste fragments. The method of dividing the tusk can also be used for the manufacture of knife handles. The knife handles are all cut from the tusk in the same direction. The average length of the waste fragments is $86.2 \mathrm{~mm}$, which corresponds with the average length of the knife handles $(84.9 \mathrm{~mm})$. The average width of the combs is however much smaller than the length of the waste fragments $(48.1 \mathrm{~mm})$. This could mean that after cutting, the blocks could be divided again for the manufacture of combs with a small width or handles with a small length. The finds represent just a small part of the waste fragments. Possibly some of the waste fragments were processed further for the manufacture of other objects. One example of such a piece is an ivory waste fragment from Amsterdam, which at one end was made into an earscoop. It was discarded before it could be finished, however.

\section{Ivory Objects in Daily Life}

Ivory objects are often viewed as luxury objects. However, the large import of elephant ivory and the many objects of elephant ivory show that ivory was not a luxury material anymore in seventeenth- and eighteenth-century Amsterdam. Combs of ivory designed to remove lice and nits from the hair can hardly be seen as luxury objects. The combs were all made in the same way, and the process of making a comb is not complicated. The combs show little ornamentation and are not always neatly finished. The comb makers used elephant ivory because it is a strong material and less easy to break than bone; it is not possible to make these kinds of combs from a material like bone. Ivory was readily available during this period. Lice combs were not a display of luxury, but an article of use. The combs show scratches from cleaning the comb and the combs were easily thrown away. Only one comb shows repair with a metal strip, held in place with metal rivets.

\section{Conclusion}

The whale hunt was important for the Dutch Republic in the seventeenth and eighteenth centuries. Products such as blubber and baleen sheets were imported and

Fig. 13 Cross-section of a comb

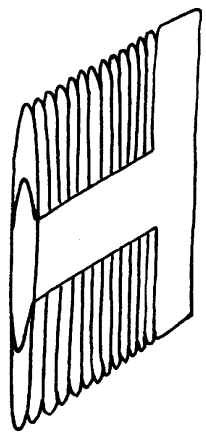


processed. Baleen was an important raw material for the manufacture of corset strips. The baleen sheets were used intensively and different specialists were involved in processing baleen. The Dutch whale hunt and the use of baleen in the seventeenth and eighteenth centuries are well-known from historical sources, but clearly not visible in archaeological sources in the Netherlands. Two small pieces of baleen from Amsterdam are the only archaeological finds of baleen in the Netherlands so far. Oil was obtained from whale bones and bones were used as building materials. Historical and archaeological sources show that whale bone was not an important material for the manufacture of small objects and was not used by professional artisans.

The minor importance of walrus ivory appears in historical as well as archaeological sources. The walrus hunt was connected to the whale hunt, but seemed to play an unimportant role for the Republic. Walruses were a secondary catch for the whale hunters, and the walrus hunt initiated from the Republic probably died out very quickly. Walrus ivory was also imported from Russia. Another product from walruses used in the manufacture of knife handles is the large and solid baculum. Walrus ivory and walrus bacula were not imported in large amounts to the Republic but were used by professional artisans. Knife makers in Amsterdam manufactured knife handles of these materials but not in large amounts.

Both historical and archaeological sources show the importance of the elephant ivory trade and craft. Elephant ivory was imported in large quantities in the seventeenth and eighteenth centuries. Archaeologists have found large numbers of objects made of elephant ivory in excavations in Amsterdam. The percentage of elephant ivory objects is even higher than the percentage of bone objects in the seventeenth and eighteenth centuries. Elephant ivory became a raw material that was used for luxury and everyday objects. Objects like lice combs were widespread in Amsterdam and were widely available. After the eighteenth century, the finds of ivory declined rapidly. The sources provide strong evidence that the manufacture of ivory combs was a specialist's trade. Ivory comb makers worked and trained in Amsterdam.

Acknowledgments I would like to thank Louise van Wijngaarden-Bakker of the Amsterdam Archaeological Centre, University of Amsterdam (AAC); Jerzy Gawronski and Wiard Krook of the Archaeological Services Amsterdam (Afdeling Archeologie BMA); Sonia O'Connor (University of Bradford); Adrie en Ineke Vonk, Texel; Klaas Post, Urk; Anneke Dekker (AAC); Rik Maliepaard (AAC); Kees Troostheide (AAC) and Ans Nieuwenburg-Bron, Hilversum (2008).

Open Access This article is distributed under the terms of the Creative Commons Attribution Noncommercial License which permits any noncommercial use, distribution, and reproduction in any medium, provided the original author(s) and source are credited.

\section{References}

Brongers J. A. (1995) Walvissen en Stadhuizen, AD and L, Amsterdam.

Bruijn J. R., Davids C. A. (1975) Jonas vrij, De Nederlandse walvisvaart, in het bijzonder de Amsterdamse, in de jaren 1640-1664. Economisch-en Sociaal-historisch Jaarboek 38:141-178.

Coolhaas, W. P., and van Goor, J. (1988). Generale missiven van gouverneurs-genraal en raden aan Heren XVII der Vernigde Oostindische Compagnie, Part IX, 1729-1737, Rijksgeschiedkundige Publicatiën 205, Nijhoff,'s Gravenhage. 
Coolhaas, W. P., and van Goor, J. (2004). Generale missiven van gouverneurs-generaal en raden aan Heren XVII der Verenigde Oostindische Compagnie, Part X, 1737-1743, Rijksgeschiedkundige Publicatiën 250, Nijhoff,'s Gravenhage.

de Jong D. (1784-86) De Walvischvangst. P. Conradi/V. van der Plaats, Amsterdam/Harlingen.

de Jong C. (1972-79) Geschiedenis van de oude Nederlandse walvisvaart, (Parts I-III). Universiteit van Suid-Afrika, Pretoria.

Dekker P. (1971) De laatste bloeiperiode van de Nederlandse Arctische walvis- en robbevangst. Europese Bibliotheek, Zaltbommel.

Dekker P. (1976) Ruilhandel met de Groenlanders. West-Frieslands Oud en Nieuw 43:103-111.

Dekker P. (1994) Onbekende Nederlandse walvisvaart en de naamgeving van de Afrikaanse Walvisbaai. Tijdschrift voor Zeegeschiedenis 13(1):41-50.

den Heijer H. (1997) Goud, ivoor en slaven. Walburg Pers, Zutphen.

den Heijer H. (2002) De geschiedenis van de WIC, 2nd edn. Walburg Pers, Zutphen.

Espinoza E. O., Mann M. (1992) Identification Guide for Ivory and Ivory Substitutes. World Wildlife Fund, Michigan.

Feinberg H. M., Johnson M. (1982) The West-African ivory trade during the eighteenth century: The "... and ivory" complex. International Journal of African Historical Studies: 15:435-453.

Frank S. M. (2005) Transformations: Dutch whaling in the Arctic 1595-1795. In: Daalder R., Loomeijer F., Wildeman D. (eds) Koersvast, Vijf eeuwen navigatie op zee. Aprilis, Zaltbommel, pp 202-212.

Gaastra F. S. (2002) De geschiedenis van de VOC, 7th edn. Walburg Pers, Zutphen.

Hacquebord L. (1994) Van Noordse Compagnie tot Maatschappij voor de Walvisvaart. Honderd jaar onderzoek naar de geschiedenis van de Nederlandse walvisvaart. Tijdschrift voor Zeegeschiedenis 13 (1): $19-40$.

Hacquebord L. (2005) Hout vrede met de mense en oorlog met de vis. Een nieuwe Chronyke 22(2):104115.

Hacquebord L., Leinenga J. R. (1994) De ecologie van de Groenlandse walvis in relatie tot walvisvaart en klimaatveranderingen in de zeventiende en achttiende eeuw. Tijdschrift voor Geschiedenis 107:415438.

Hacquebord L., Vroom W. (1988) Walvisvaart in de gouden eeuw:Opgravingen op Spitsbergen. De Bataafsche Leeuw, Amsterdam.

Hart S. (1976) Geschrift en getal: Een keuze uit de demografisch-, economisch- en sociaal-historische studiën op grond van Amsterdamse en Zaanse archivalia, 1600-1800. Historische Vereniging Holland, Dordrecht.

Honig, J. (1867). De Groenlandsche en Straat Davissche visscherij, Historische Oudheden en Letterkundige Studiën, Part 2, 1-172, Heijnis, Zaandijk.

Houttuijn M. (1761) Natuurlijke historie of uitvoerige beschrijving der dieren, planten en mineraalen. Eerste deels, tweede stuk, Vervolg der zoogende dieren. F. Houttuijn, Amsterdam.

Lauffenburger J. A. (1993) Baleen in museum collections: its sources, uses, and identification. Journal of the American Institute for Conservation 32:213-230.

Lauwerier R. C. G. M. (1983) Walviskaken op het droge. Westerheem 32(4):236-239.

Leinenga J. R. (1995) Arctische walvisvangst in de achttiende eeuw. De Bataafsche Leeuw, Amsterdam.

Lootsma S. (1937) Bijdrage tot de geschiedenis der Nederlandsche walvisvaart (meer speciaal de Zaansche). Van Kampen, Amsterdam.

Luijken J., Luijken K. (1694) Spiegel van het menselijk bedrijf. A.W Sijthoff, Leiden.

MacGregor A. (1985) Bone, Antler, Ivory and Horn. Croom Helm, London.

MacGregor A. G., Currey J. D. (1983) Mechanical properties as conditioning factors in the bone and antler industry of the 3rd to the 13th century AD. Journal of Archaeological Science 10:71-77.

Martens F. (1710) Nauwkeurige beschryvinge van Groenland of Spitsbergen. wed. Gijsbert de Groot, Amsterdam.

Mooy H. (1946) Naar Groenland met de Frankendaal. Wereldbibliotheek, Amsterdam.

Muller S. (1874) De geschiedenis der Noordsche Compagnie. Van der Post, Utrecht.

Muller S. (1915) John Osborn. Oud-Holland 33:199-207.

Münzing J. (1987) Der historische Walfang in Bildern. Koehler, Herford.

O'Connor S. (1987) The identification of osseous and keratinaceous materials at York. In: Starling K., Watkinson D. (eds) Archaeological Bone, Antler and Ivory. United Kingdom Institute for Conservation, London, pp 9-21.

Oldewelt W. F. H. (1945) Kohier van de personeele quotisatie te Amsterdam over het jaar 1742. Genootschap Amstelodamum, Amsterdam. 
Penniman T. K. (1952) Pictures of Ivory and Other Animal Teeth, Bone and Antler. Oxford University Press, Oxford.

Postma J. M. (1973) West African exports and the Dutch West India Company. Economisch-en Sociaalhistorisch Jaarboek 36:53-74.

Rajaram A. (1986) Tensile properties and fracture of ivory. Jounal of Materials Science 5:1077-1080.

Rijkelijkhuizen, M. J. (2004). Dierlijke materialen in Amsterdam, Unpublished master's thesis, University of Amsterdam.

Schelvis J. (1992) Luizen, neten en vlooien. In: Broekhuizen P. H. (ed) Van Boerenerf tot Bibliotheek. Stichting Monument and Materiaal, Groningen, pp 517-523.

Thornton, J. (1981). The structure of ivory and ivory substitutes. Preprints of 9th annual meeting of the American Institute for Conservation of Historic Works, pp. 173-81.

van Bree P. J. H. (1996) Walrussen in Amsterdam. Ons Amsterdam 46:309-311.

van Dillen, J. G. (1929). Bronnen tot de geschiedenis van het bedrijfsleven en het gildewezen van Amsterdam, part I, 1512-1611, Rijksgeschiedkundige Publicatiën 69,'s Gravenhage.

van Nierop L. (1915) Uit de bakermat der Amsterdamsche handelsstatistiek. Jaarboek Amstelodamum 13:102-172.

van Thiel P. J. J. (1969) Hollandse lijsten van balein. In: Zadoks-Josephus J. (ed) Miscellanea I.Q. van Regteren Altena. Scheltema and Holkema, Amsterdam, pp 104-110.

van Thiel P. J. J., de Bruyn Kops C. J. (1984) Prijs de lijst. Rijksmuseum Amsterdam, Amsterdam.

Veluwenkamp J. (2000) Archangel: Nederlandse ondernemers in Rusland 1550-1785. Balans, Amsterdam.

Wagemakers P. (1992) Traan- en baleinverwerking. Ons Amsterdam 44:128-131.

Wijnroks E. H. (2003) Handel tussen Rusland en de Nederlanden, 1560-1640, Verloren, Hilversum.

Zorgdrager C. G., Moubach A. (1727/28) Bloeijende opkomst der aloude en hedendaagsche Groenlandsche visscherij (2nd ed), P. van Thol/R.C. Alberts, Den Haag/Amsterdam. 